\title{
INFORMATION TECHNOLOGY AS MODERATOR BETWEEN KNOWLEDGE MANAGEMENT AND ORGANIZATIONAL PERFORMANCE
}

\author{
Yassine Boussenna ${ }^{1}$, Ouail El Kharraz ${ }^{2}$ \\ Research group: Management \& Information System, National School of Business and Management Tangier,
} Morocco.

\begin{abstract}
The main objective of this study was to verify the moderating role of Information Technology on the relationship between KM implementation and organizational performance in a university context through Abdelmalek Essaadi University. by collecting the views of teacher-researchers, using a hypothetical-deductive reasoning approach and a quantitative working method. Our questionnaire was administered to a representative sample of 88 teacher-researchers from the different institutions of the university under study.

The results obtained using Hierarchical regression prove the moderating and positive role of Information technology on the intensity of the relationship between the application of the KM and (Training, research, publication, and governance) as indicators of organizational performance with a change in the correlation rate from $R=0.917$ to $R=0.974$ with the addition of leadership as a moderator variable with a degree of impact of $5.7 \%$.

This paper presents empirical evidence on the importance of the organizational, technical, and human factors on knowledge management implementation and enhancing performance.
\end{abstract}

KEYWORDS: organizational performance, Information Technology, knowledge management.

\section{INTRODUCTION}

Knowledge management developed mostly in the knowledge-intensive organizations because of the dominance of intangible resources and knowledge capabilities. Universities are such knowledge-intensive organizations, and that is a crucial argument as to why knowledge management impacts the whole academic management and leadership as well as the students' education. Although universities are based on teaching and learning processes, they are not, by definition, learning organizations. They must develop powerful knowledge management systems and design knowledge strategies for becoming learning organizations characterized by generative learning processes (Shattuck 2006, Bratianu \& Pinzaru, 2015).

Knowledge management also plays an important role in the development of institutions, especially universities, because of its intellectual and knowledge assets. Therefore, it has become more capable of keeping pace with development and achieving excellence in the knowledge society (Arqawi et al, 2018).

On the other hand, and throughout the literature, several factors positively affecting KM initiatives in public organizations and specifically in universities are discussed. For Ranjan and Bhatnagar (2008), these are factors or parameters necessary for the continued success of an organization and these factors represent the areas of management that require special and continuous attention to achieve high performance. Some are the same as those identified for private organizations and others are specific to public organizations. Most authors (Butler \& Murphy, 2007; Cong, 2008; Ansari et al. 2012) cite several factors; but in this article, we will focus on information technology.

Effective knowledge management (KM) requires appropriate use of organizational strategies as well as information technology (IT). Our definition of IT includes computers and communications technologies, $\mathrm{T}$ is likely to play a crucial role in implementing most KM initiatives.

also several researchers have insisted on the importance of information technology (IT) to support the creation, storage, retrieval, transfer and application of knowledge in organizations by data mining and learning tools, knowledge repositories, databases, electronic bulletin boards, discussion forums, intranets, email, calendaring tools, collaboration tools, including text-based and audio chat tools, telecommunication and video-conferencing ( Stankosky, 2005; Arntzen et al, 2009; Gill, 2009 ; Tian et al, 2009; Eftekharzade and Mohammadi, 2011; Ramachandran et al, 2013 ; and Fullwood et al, 2013).

In addition, many studies have addressed the issue of the importance of the application of K.M for organizations such as improving innovation and creativity, product quality, and organizational performance (le et al, 2009; 
Mills \& Smith, 2011; Reich et al, 2013; Lee \& Tseng, 2014; Alaarj et al,.2016; Novak, 2017; Adams, \& Graham, 2017; Shamia et al.,2018; Abu-Bakr, et al ,2018; Ernest et, al 2020; Sahibzada et al, 2020; Salaam, 2020; Wenjiao \& Yang 2020; El kharraz \& Boussenna, 2020).

It's important at this level to note that information technology is a success factor of knowledge management and also a tool of performance, but how it can play a moderating role between the two is not well demonstrated and especially in university context.

The purpose of the present research is to analyze specifically the moderating effect of IT on the relationship between KM implementation and organizational performance at Abdelmalek Essaadi University the point of view of teacher-researchers.

\section{THORETICAL BACKGROUND AND RESEARCH MODEL}

\subsection{Knowledge management in the university context}

Universities are knowledge-intensive organizations because all the basic processes employ data, information, and knowledge. Teaching is essentially a transfer of knowledge from professors to students, but it involves many activities and tasks of data, information, and knowledge collection, selection, structuring, and integration into ideas and theories, which correspond to a certain conceptual framework. Teaching can be performed directly in classrooms or online by using specialized platforms and indirectly through a series of printed materials or stored documents in databases. Teaching also involves knowledge sharing that reflects professors' experience (Bratianu et al, 2021).

Also, K.M plays an important role in the development of institutions, especially universities, because of its intellectual and knowledge assets. Therefore, it has become more capable of keeping pace with development and achieving excellence in the knowledge society (Arqawi et al, 2018).

\subsubsection{KM process for universities}

Knowledge assets are managed in several ways, namely: through capitalization, sharing, and knowledge creation.

There is no unified agreement among authors and researchers regarding the number of K.M processes, as different researchers define them in different ways (Costa \& Monterio, 2016) and with several models as they are defined as three stages: knowledge generation, knowledge codification, and knowledge transfer. Or four consisting of Acquiring, storing, sharing, and applying knowledge or it is a five-step process consisting of (knowledge acquisition, knowledge formation, knowledge transfer, knowledge storage, and application) (Abidi et al 2018, p 5 ).

Becerra et al, (2004) integrated the empirical research findings of Nonaka (1994) (socialization, externalization, internalization, combination), and distinguished four knowledge management processes: knowledge discovery, knowledge capture, knowledge sharing, and knowledge application.

On our part in this work, we will opt for the most used model and the most adapted to the universities in four stages consisting of acquiring, storing, sharing, and using knowledge, (Alavi \& leidner, 2001, Doueihi, 2009).

\subsection{Organizational Performance at the University}

Level Performance measurement is fundamental to all organizations including universities. Today universities are under similar pressures as different organizations to have a place in society. Significant changes in competition have prompted universities to adopt a new management system similar to businesses in that students are currently treated as customers. In addition, there are increasing demands from stakeholders (Hilman \& Abubakar, 2017).

Universities must ensure and provide students with high quality service. They have an obligation to produce graduates who can adapt to the challenges of the developing society. Other research has focused on teaching and research as indicators of performance measurement in universities (Manjarrés et al.,2009; Lukman et al.,2010; Asif et al., 2013; Asif \& Searcy, 2014).

Other researchers believe that the production of services for the community is an indicator of performance (Badri \& Abdulla, 2004; Patel et al, 2011). On the other hand, student graduation rate remains a primary indicator of university performance. Hilman \& Abubakar, (2017) stated that the undergraduate loss rate should be taken into account when assessing university performance.

\subsection{Relationship between $\mathrm{K} M$ and organizational performance:}

The link between K.M and organizational performance has been highlighted in the Knowledge-Bases View of the Firm (KBV).

First of all, it is universally known that knowledge is an important weapon to maintain a competitive advantage (Choi \& Lee 2014, p179).

This is because organizations achieve superiority in performance through a combination of their tangible resources such as natural resources and intangible resources such as knowledge (Lee \& Sukoco, 2007). The proper application of a knowledge management system can make an organization self-dependent on knowledge, which can be helpful in surviving many obstacles it may face in the short and long term. In the same sense, the success of an organization often depends on its ability to accumulate knowledge and process it to enable organizational learning (Cohen \& Sproul, 1991). Organizations also adopt K.M protocols for many reasons, including intensifying their efforts to create and share knowledge, improve internal collaboration, share best practices, provide competitive intelligence, and maintain a competitive advantage.

At the same time, the study of the link between the application of K.M and the performance of organizations has received particular attention.

Indeed, several researchers and practitioners have noticed the positive relationship between K.M and organizational performance such as improving innovation and creativity, product quality, and organizational performance (Schutte, \& du Toit, 2012; Vila et al 2015; Alaarj et al, 2016; Novak, 2017; Adams, \& Graham,2017; Abubakar et al 2019; Ernest et al 2020, Sahibzada et al, 2020, Salama, 2020, Wenjiao \& Yang, 2020, El kharraz \& Boussenna, 2020).

\subsection{Information technology}

Information and communication technologies refer to all 
techniques used in the processing and transmission of information, mainly computers, the Internet, and telecommunications.

By extension, it also refers to the economic sector of information and communication technologies.

Although old, the term technology has begun to be studied seriously as a systematic and formalized field since production techniques have become more complex.

Information Technology (IT) can be defined as the set of activities and solutions related to computer resources. IT is the "hardware-software" package dedicated to the creation of Information Systems (IS) (Balarine, 2002). IT and IS are used by individuals and organizations to support environmental change. They are used by organizations to increase production, improve products and services, and outperform competitors (Rossetti \& Morales, 2007).

\subsubsection{Information technology and KM}

Effective knowledge management (KM) requires the appropriate use of organizational strategies as well as information technology (IT) has greatly boosted knowledge management through the implementation of KMS. IT services supporting knowledge management include database decision support systems, enterprise resource planning systems, expert systems, management information systems, lessons learned systems, etc. In addition, social mechanisms also support knowledge management. On-thejob training, observational learning, face-to-face meetings, mentoring for knowledge sharing, and employee rotation between departments are examples of such mechanisms.

Technology has greatly enhanced the ability of organizations to foster the exchange of information between individuals. Information Technology (IT) has long played a fundamental role in the management of organizations. Initially, the objective was to automate business processes, the simplest tasks that support daily activities. But, today the role of IT is mostly strategic (Laudon and Laudon, 2007; Kang et al, 2012). New information and communication technologies can play a strategic role in improving organizational performance and enabling the development of sustainable competitive advantages. Indeed, the role of IT in organizations has evolved from a departmental activity to one that encompasses the entire organization. Hundreds of organizations are using IT as a competitive differentiator, such as Bradesco Bank S.A., Amazon.com, and FedEx. It is fair to say that without new information and communication technologies, KM would not be at the advanced stage it is today. Without them, the socialization and formalization of knowledge would be almost impossible in organizations (Szezerbicki et al, 2003). But what is the role of IT for KM and innovation? What tools does it have? These questions concern Dimension 5 of this research (Neves 2017 p 179).

Information technologies are present in all $\mathrm{KM}$ processes and play an important role in facilitating these processes. They are considered the most effective way to capture, store, transform and disseminate knowledge. And it is certainly thanks to this technological dimension that $\mathrm{KM}$ has become more important in organizations today. Despite this role, information technology is seen as an enabler of KM (Ikhsan \& Rowland 2004, p102).
Technology, the information technologies that support and/or enable KM strategies and operations (Stankosky, 2005) has been viewed as an enabler for KM (Arntzen et al., 2009; Gill, 2009; Eftekharzade and Mohammadi, 2011; Ramachandran et al., 2013), knowledge creation (Tian et al., 2009) and knowledge sharing (Fullwood et al., 2013) in HE. Further, there is a consensus that whilst the use of appropriate information communication technologies can help universities to move towards a knowledge-based learning organization, a 'good fit' between information technology, socio-organizational factors, and sustainable organizational culture is also required (Arntzen et al., 2009; Gill, 2009; Adhikari, 2010). On the other hand, two recent studies disagree on the importance of IT in knowledge sharing. In the UK, Fullwood et al. (2013) found that academics were neutral as regards the importance of technology, possibly due to their high level of autonomy and engagement in disciplinary communities. But, in public universities in Malaysia, Ramachandran et al. (2013), identified IT as the most extensively used KM strategic enabler.

IT plays the role of a backup for knowledge stores and knowledge bases in the context of KM. They also facilitate access to and transmission of knowledge and promote interactions between individuals, groups, and organizations. In addition, they can contribute to the knowledge creation process especially in scientific settings (Ansari et al. 2012, p.216).

The main factors identified related to information technology that can foster KM are the following (Ansari et al. 2012, p.216; Cong 2008, p.115; Cong \& Pandya 2003, p.31; Ikhsan \& Rowland 2004, p.102):

- A technological infrastructure for access and sharing;

- Access to applications;

- Technological know-how.

the various theoretical arguments and empirical studies presented previously allowing us to deduce the hypothesis of this article:

"The Information technology positively moderates the relationship between knowledge management implementation and organizational performance of Abdelmalek Essaadi University from the point of view of research teachers".

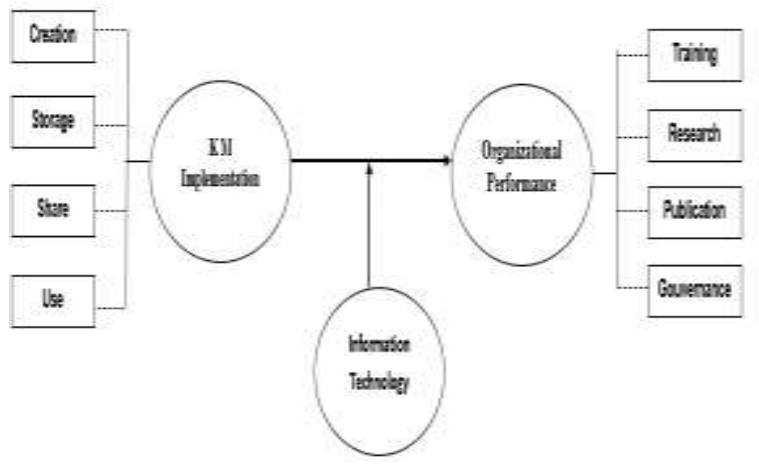

Fig.1: the research model

\section{METHODS}

\subsection{The sample of our study}

We administered a questionnaire to a representative sample of 88 teacher-researchers from the various 
institutions of Abdelmalek Essadi University, the survey was done between September and October 2020.

\subsection{Our Data Collection Tool}

In order to meet the needs of our study, a questionnaire with nine indices and 40 questions was designed. However, we feel it is necessary to ensure the validity and reliability of our tool.

\subsubsection{Content validity}

In order to ensure the content validity of our questionnaire, we followed the steps below: First, we conducted extensive research on the topic and then specified the structure of the field under study. Then we consulted specialists in the field of knowledge management and management control, primarily.

\subsubsection{Analysis of questionnaire reliability}

To address the issue of the reliability of the questions asked in a test, we calculated Cronbach's alpha coefficient. The table below shows the value of the coefficient for all chapters of our research using SPSS software:

Table 1:Questionnaire Reliability

\begin{tabular}{|c|c|c|}
\hline Study Variables & Chapter & Cronbach's $\alpha$ \\
\hline Knowledge management & $1-15$ & 0.957 \\
\hline Information Technology & $16-20$ & 0.712 \\
\hline Organizational performance & $21-25$ & 0,973 \\
\hline
\end{tabular}

From the data in the table above we notice that the value of Cronbach's alpha for all chapters in our research is between 0.712 and 0.973 .

Therefore, these values are well above 0.7 which confirms the internal consistency and reliability of our questionnaire.

\section{RESULTS AND DISCUSSIONS \\ 4.1 Descriptive statistics \\ Descriptive results for IT}

Table 2: Descriptive results for IT

\begin{tabular}{|c|c|c|c|}
\hline Information and technology & mean & S.D & level \\
\hline $\begin{array}{c}\text { At the university, there is a general Internet access service for } \\
\text { all teachers-researchers. }\end{array}$ & 2,63 & 1,15 & Medium \\
\hline $\begin{array}{c}\text { The existing IT infrastructure at the university offers an } \\
\text { internal information network to access databases (computers, } \\
\text { archiving systems). }\end{array}$ & 2,39 & 0,88 & Low \\
\hline $\begin{array}{c}\text { The university is committed to organizing electronic forums } \\
\text { that contribute to the documentation and exchange of } \\
\text { knowledge. }\end{array}$ & 2,36 & 0,98 & Low \\
\hline $\begin{array}{c}\text { The university has an electronic infrastructure that contributes } \\
\text { to the holding of meetings and teleconferences and the } \\
\text { sharing of experiences at a distance. }\end{array}$ & 2,09 & 0,79 & Low \\
\hline $\begin{array}{c}\text { The administration has an electronic librany that allows } \\
\text { teachers-researchers to take advantage of it. }\end{array}$ & 2,00 & 1,21 & Low \\
\hline \begin{tabular}{c} 
Overall average \\
\hline
\end{tabular} & 2,29 & 0,51 & Low \\
\hline
\end{tabular}

The $\mathrm{T}$ value in the table $=1.96$, with a significance level $\alpha=0.05$, and a mean level between (2.34 and 3.67)
These results obtained clearly illustrate the lack of presence of knowledge management factors at the level of the various institutions of the University Abdelmalek Essaadi from the point of view of teachers and more precisely the I.T.

\subsection{HYPOTHESIS TESTING :}

This section has a main objective, to test the moderating effect of I.Tusing hierarchical multiple regression.

\section{Table 3: Hierarchical regression moderation}

\begin{tabular}{|c|c|c|c|c|c|c|c|c|c|c|}
\hline \begin{tabular}{|c|c|} 
The depeadeat \\
mariable
\end{tabular} & \multirow{2}{*}{$\begin{array}{c}\text { Tht } \\
\text { intependent } \\
\text { rariahle }\end{array}$} & \multicolumn{3}{|c|}{ First nedel } & \multicolumn{3}{|c|}{ Second nodel } & \multicolumn{3}{|c|}{ Third model } \\
\hline \multirow{9}{*}{$\begin{array}{l}\text { Organizational } \\
\text { performance }\end{array}$} & & Beta & $\mathrm{I}$ & $\mathrm{Sg}$ & Beta & $\mathrm{T}$ & $\mathrm{Sg}$ & Betz & $\mathrm{I}$ & Sig \\
\hline & $\begin{array}{l}\text { Knorkelge } \\
\text { masegenent }\end{array}$ & 0.878 & 17012 & 0.000 & & & & & & \\
\hline & 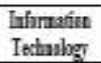 & & & & 0.382 & 39 & 0.02 & & & \\
\hline & $\begin{array}{l}\text { Troorletge } \\
\text { manngemeat } \\
\text { +ET }\end{array}$ & & & & & & & 0.144 & $2 \pi 72$ & 0.007 \\
\hline & $\mathrm{R}$ & & 0.917 & & & 0.383 & & 0974 & & \\
\hline & $\mathbb{R}^{2}$ & & 0.771 & & & 0.151 & & 0.790 & & \\
\hline & $\Delta \mathbb{R}^{2}$ & & 0.771 & & & 0.151 & & 0.057 & & \\
\hline & $\Delta \mathrm{F}$ & & 299.400 & & & 15251 & & 7.624 & & \\
\hline & $\triangle \mathrm{Sig}$ & & 0.000 & & & 0.000 & & 0.027 & & \\
\hline
\end{tabular}

From Table 3 showing the results of hierarchical multiple regression for the first model the value of the correlation coefficient $\mathrm{R}=0.917$ which implies a statistically significant relationship between knowledge management and organizational performance at the level of the different institution of Abdelmalek Essaadi University. also note that the value of $F=289$ showing a positive and significant effect of knowledge management on organizational performance at a level of significance $\alpha=0.05$, in the same sense the value of the coefficient of determination $\mathrm{R}^{2}$ $=0.771$ explains that $77.1 \%$ of the variation in organizational performance at the different institutions of the University Abdelmalek Essaadi according to teacher's researchers is due to the application of knowledge management. Also, the value of Beta $=0.878$ predicts the variation of organizational performance of 0.878 when there will be an increase in the application of knowledge management by one degree at the level of Abdelmalek Essaadi University from the point of view of research teachers.

Regarding the results of the second model that relates the organizational performance with the leadership of the management of each institution we report:

Firstly, that the value of the correlation coefficient $\mathrm{R}=$ 0.388 implies a statistically significant relationship between information technology and communication and organizational performance at the level of the various institutions of the University Abdelmalek Essaadi. Note also that the value of $F=15.251$ showing a positive and significant effect of information technology and communication on organizational performance at a level of significance $\alpha$ less than 0.05 , in the same sense the value of the coefficient of determination $\mathrm{R}^{2}=0.151$ explains that $15.1 \%$ of the variation in organizational performance at the level of different institutions of Abdelmalek Essaadi University according to teacher's researchers is due to information technology and communication. also, the value of Beta $=0.388$ predicts the variation in organizational 
performance of 0.388 when there will be an increase in information technology and communication of one degree at the level of Abdelmalek Essaadi University from the point of view of teacher's researchers.

About the third model, we entered the information technology and communication as the third variable by examining its moderating role on the relationship between knowledge management and organizational performance we noticed a slight increase of $5.7 \%$, so that the correlation coefficient will be $\mathrm{R}=0.974$ and this increase and statistically significant with a $\mathrm{T}=2.772$ greater than 1.96 with a significance level $\leq 0.05$ showing a value of 0.007 on the table.

This confirms the positive moderating role of information technology and communication on the relationship between knowledge management and organizational performance at the different institutions of Abdelmalek Essaadi University from the point of view of teachers-researchers, with a degree of impact of $5.7 \%$ confirming the hypothesis of this article.

\section{DISCUSSIONS}

These results coincide with our previous research on the moderating effect of Humain, organizational and technical factors such as (culture, organizational structure) on the relationship between $\mathrm{KM}$ and organizational performance in the university context (Boussenna, 2021, El kharraz\& Boussenna,2021).

Similarly, the results obtained coincide with the results obtained by other researchers including the work of (Salama, 2020), which confirms the direct impact of the availability of K.M infrastructure on the performance of the education sector in Libya from the point of view of 612 staff of the same sector.

(Cardona et al 2013; El Idrissi , 2010 ; Melville et al 2004) assert that organizations seek to create value by implementing information systems that generate tangible and intangible gains. To do this, they continue to invest in information systems to improve their performance and generate results.

Note that several Researchers have identified the positive impact of information technology (IT) artefactsto support the creation, storage, retrieval, transfer and application of knowledge in organizations (Ansari et al. 2012; Cong 2008; Cong \& Pandya 2003; Ikhsan \& Rowland 2004).

In addition, information technologies support KM strategies and operations (Stankosky, 2005) or has been viewed as an enabler for KM (Arntzen et al., 2009; Gill, 2009; Eftekharzade and Mohammadi, 2011; Ramachandran et al., 2013), knowledge creation (Tian et al., 2009) and knowledge sharing (Fullwood et al., 2013) in higher education.

This results leads the university leaders to provide more effort to improve the information technology infrastructure in Abdelmalek Essaadi University through:

The involvement of the university in the organization of electronic forums that contribute to the documentation and exchange of knowledge.

the presence of an electronic library allowing teachersresearchers to take advantage of it.

\section{CONCLUSION}

Knowledge management in Moroccan universities is a relatively young field of study. This research explored the knowledge management in Moroccan higher educational institutions through Abdelmalek Essaadi University, and the examination of the moderating role of IT on the intensity of relationship between KM implementation and the organizational performance from the point of view of teacher-researchers of Abdelmalek Essaadi University.

One of the main theoretical contributions of our research lies in the fact that we relied on a multidisciplinary theoretical framework mobilizing theories from different disciplines, namely the Knowledge Based View (KBV), which proposes to introduce a new vision of the firm. These theories allowed us to highlight the link between knowledge management and organizational performance. and the approach of key success factors, linking the success of the application of knowledge management to organizational, technical and human factors encompassed in (Information technology). Better still, our approach to the problem was strongly anchored in this theoretical corpus, by trying to orient our reflection both theoretically and empirically, by situating it in this conceptual framework.

while, The empirical phase of our work used a quantitative approach, an approach that is increasingly developed in management sciences and precisely the study of higher educational institutions .

Additionally, an increase in the size of our samples per establishment could perhaps better explain the influence of knowledge management for each establishment. As well, the choice of a single region (Tangier-Tetouan-Al Hoceima) in this article pushes us to expand our field of work for future work to cover the national territory in its entirety.

further, in our future work, we will study other success factors of knowledge management initiatives.

Moreover, it should be noted that this research has important implications for the leaders of Moroccan universities. The confirmation of the hypotheses of our work reminds us that each university must clearly define its strategy based on better knowledge management as a cornerstone of any action aiming at excellence and organizational performance, and consequently the improvement of its competitiveness at the international level.

Finally, our research constitutes a line of thought for researchers wishing to strengthen research related to knowledge management in the university environment and especially in Morocco.

\section{REFERENCES}

1. Abidi, W,. Sanchez, M.Aoiz,G,.(2018), Phenotypic and biochemical diversity in peach [Prunus persica (L.) Batsch] cultivars. Journal of New Sciences. Agriculture and Biotechnology 51 (5): 3171-3178.

2. Abubakar, A,. Hilman ,H,. Kaliappen , N. ( 2018 ). New Tools for Measuring Global Academic Performance, DOI: 10.1177/2158244018790787 journals.sagepub.com/home/sgo.

3. Adams, F,. \& Graham, $K$.(2017 ). Integration, knowledge creation and $B 2 B$ governance: The role of resource hierarchies in financial performance, 
Industrial Marketing Management.

4. Akram, M.U., Chauhan, C., Ghosh, K. and Singh, A. (2019), "Knowledge management, sustainable 11(2), 57-62.

5. Alaarj, S,. Zainal, A, ,. Ummi,S . (2016). Turkey Mediating Role of Trust on the Effects of Knowledge Management Capabilities on Organizational Performance, 12th International Strategic Management Conference, ISM, Antalya .

6. Alavi , M ., \& Leidner, D. (2001). Review: Knowledge Management and Knowledge Management Systems: Conceptual Foundations and Research Issues. MIS Quarterly, 25(1), 107-136. DOI: $10.2307 / 3250961$.

7. Ansari, M., Youshanlouei, H,. Mood, M. (2012).A Conceptual Model for Success in Implementing Knowledge Management: A Case Study in Tehran Municipality. Journal of Service Science and Management, 05(02), pp.212-222.

8. Arntzen, A.A.B., Worasinchai, L. and Ribière, V.M. (2009), "An insight into knowledge management practices at Bangkok University", Journal of Knowledge Management, Vol. 13 No. 2, pp. 127-144.

9. Arqawi,M Amal, A,. Samy S. Abu Naser. Al Shobak,M,. ( 2018), Obstacles to the Application of Knowledge Management from the Point of View of the Employees at the Technical University of Palestine, International Journal of Academic Information Systems Research (IJAISR) ISSN: 2000002X Vol. 2 Issue 9, September - 2018, Pages: 1-16.

10. Asif, M, \& Searcy, C. (2014). "Determining the key capabilities required for performance excellence in higher education", Total Quality Management \& Business Excellence Journal, Vol. 25 Nos 1/2, pp. 22-35.

11. Asif, M., Raouf, A,. Searcy, C. (2013). "Developing measures for performance excellence: is the Baldrige criteria sufficient for performance excellence in higher education?", Quality \& Quantity, Vol. 47 No. 6, pp. 3095-3111.

12. Badri, M, \& Abdulla,M. (2004). "Awards of excellence in institutions of higher education: an AHP approach", International Journal of Educational Management, Vol. 18 No. 4, pp. 224-42.

13. Balarine, O. (2002). Tecnologia da informação como vantagem competitiva. RAE-Eletrônica, 1(1), 1-11. Disponible http://www.scielo.br/pdf/raeel/v1n1/v1n1a05

14. Batista, F. F. (2012). Modelo de Gestão do Conhecimento para a Administração Pública Brasileira. Brasília: Instituto de Pesquisa Econômica Aplicada (Ipea).

15. Becerra,. \& Gonzales,I.(2004). A Knowledge Management, Chalanges, Solutions and Technologies .

16. BOUKER, M.A. (2017). Les communautés d'apprentissage professionnelles en ligne : un moyen de développement professionnel d'acteurs en éducation (Thèse de doctorat non publiée). Université Laval, Québec, Canada.

17. BOUSSENNA, Y. (2021). Knowledge management and academic performance moderating role of organizational structure: Abdelmalek essaadi university case. International Journal of Financial Accountability, Economics, Management, and Auditing (IJFAEMA), 3(3), 145-158. https://doi.org/10.52502/ijfaema.v3i3.61.

18. Bratianu, C.; Pinzaru, F. (2015), University governance as a strategic driving force. In
Proceedings of the 11th European Conference on Management, Leadership, and Governance, Military Academy, Lisbon, Portugal; Dias, J.C., Ed.; Academic Conferences and Publishing International: Reading, UK, pp. 28-35.

19. Bratianu, C.; Stanescu, D.F.; Мосаnu, R. (2021), Exploring the Knowledge Management Impact on Business Education. Sustainability, 13, 2313. https://doi.org/10.3390/su13042313.

20. Butler,T., Murphy, C. (2007). Implementing Knowledge Management Systems in Public Sector Organisations: A Case Study of Critical Success Factors. In H. Österle, J. Schelp, \& R. Winter, eds. 15th European Conference on Information Systems. University of St. Gallen, pp. 612-623.

21. Cardona, Kretschmer, \& Strobel (2013), ICT and productivity: conclusions from the empirical literature, Information Economics and Policy, Volume 25, Issue 3, pp 109-125 https://doi.org/10.1016/j.infoecopol.2012.12.002.

22. Choi, B., \& Lee, H. (2014). Knowledge Management Enablers, Processes, and Organizational Performance: An Integrative View and Empirical Examination, Journal of Management Information Systems / Summer 2003, Vol. 20, No. 1, pp. 179-222.

23. Cohen, M.D., \& Sproul, L.E. (1991). 'Editors' Introduction', Organization Science 2(1): 1-3 (Special issue on Organizational Learning - Papers in honor of [and by] James G. March).

24. Cong, X., \& Pandya, K. V. (2003). Issues of Knowledge Management in the Public Sector. Electronic Journal of Knowledge Management, 1(2), pp.25-33.

25. Cong, X., (2008). Towards a framework of knowledge management in the chinese public sector: a case study of china customs. Northumbria University.

26. Costa , V., Monteiro. (2016). Key knowledge management processes for innovation: a systematic literature review, VINE Journal of Information and Knowledge Management Systems, ISSN: 2059-5891.

27. Costa , V., Monteiro. (2016). Key knowledge management processes for innovation: a systematic literature review, VINE Journal of Information and Knowledge Management Systems , ISSN: 2059-5891.

28. DIMMOCK, C. (2016). Conceptualising the research-practice-professional development nexus: Mobilising schools as "research-engaged" professional learning communities. Professional Development in Education, 42(1), 36-53

29. Doueihi, M. (2009). La grande conversion numérique Seuil, Paris, 271 https://doi.org/10.4074/S0336150009002129

30. Drucker, P. (1993)."The rise of the knowledge society." The Wilson Quarterly, vol. 17, no. 2, p. $52+$.

31. Drucker, P. (2001). Innovation and Entrepreneurship. New York: First Harper Business.

32. Dudézert, A., \& Lancini, A . (2006). Performance et Gestion des Connaissances : contribution à la construction d'un cadre d'analyse. Journées des IAE, Congrès $d u$ cinquantaire, Montpellier, https://doi.org/10.1007/BF01384902.

33. Eftekharzade, S.F. and Mohammadi, B. (2011), "The presentation of a suitable model for creating knowledge management in educational institutes (higher education)", Procedia - Social and Behavioral Sciences, Vol. 29, pp. 1001-1011. Fullwood, R., Rowley, J. and Delbridge, R. (2013), 
"Knowledge sharing amongst academics in UK universities", Journal of Knowledge Management, Vol. 17 No. 1, pp. 123-136.

34. EL KHARRAZ, O ; BOUSSENNA, Y.(2021), Moderating effect of culture on the relationship between knowledge management and organizational performance in the university context. IJBTSR International Journal of Business and Technology Studies and Research, [S.l.], v. 3, n. 2, p. 16 pages, july 2021. ISSN 2665-7716. doi: https://doi.org/10.5281/zenodo.5146224.

35. El Kharraz, O., \& Boussenna, Y. (2020). Knowledge management and organizational performance: Abdelmalek Essaadi university cases. International Journal of Accounting, Finance, Auditing, Management and Economics, 1(3), 149-168. https://doi.org/10.5281/zenodo.4281558.

36. Ernest, E., Ngamoe, B ., Villeneuve, A . (2020). L'influence des pratiques de gestion des connaissances dans le processus de gestion stratégique des TI, International Journal of Business and Technology Studies and Research, ISSN: 26657716 , Volume 2, Issue 1.

37. Forcadell, F. J., et Guadamillas, F. (2002). A case study on the implementation of a knowledge management strategy oriented to innovation. Knowledge and Process Management, 9(3), 162171. doi:10.1002/kpm.143

38. Freeman, E . (1984) . Strategic Management: A Stakeholder Approach,

39. Gill, A. (2009), "Knowledge management initiatives at a small university", International Journal of Educational Management, Vol. 23 No. 7, pp. 604616.

40. HUFFMAN, J.B., OLIVIER, D.F., WANG, T., CHEN, P., HAIRON, S. et PANG, N. (2016). Global conceptualization of the professional learning community process: Transitioning from country perspectives to international commonalities. International Journal of Leadership in Education, 19(3), 327 351. doi: org/10.1080/13603124.2015.1020343

41. Ikhsan, S.O.S. \& Rowland, F., 2004a. Benchmarking knowledge management in a public organisation in Malaysia. Benchmarking: An International Journal, 11(3), pp.238-266.

42. Kang, Y., O'Brien, W. J., Dai, J., Mulva, S., Thomas, S. P., Chapman, R. E., et Burty, D. (2012). Interaction Effects of Information Technologies and Best Practices on Construction Project Performance. Journal of Construction Engineering and Management, 139(April), 361-372. doi:10.1061/(ASCE)CO.1943-7862.0000627.

43. Laudon, K. C., et Laudon, J. P. (2007). Sistemas de Informação Gerenciais. São Paulo: Pearson Prentice Hall.

44. Lee, L.T., \& Sukoco, B.M. (2007). The effects of entrepreneurial orientation and knowledge management capability on organizational effectiveness in Taiwan: the moderating role of social capital, International Journal of Management, 24(3), 549- 73.

45. Lee, Sh., \& Tseng, P. (2014). The Effect of Knowledge Management Capability and Dynamic Capability on Organizational Performance, Journal of Enterprise Information Management, 27: 1-43.

46. LIKERT, R. (1961). New patterns of management. New York, NY: McGraw-Hill.

47. Lin,. \& lee . (2005). Spoken document understanding and organization, IEEE Signal Processing Magazine (Volume: 22, Issue: 5) , PP: $42-60$, DOI: 10.1109/MSP.2005.1511823.

48. Lukman, R., Krajnc, D., Glavič, P. (2010). University ranking using research, educational and environmental indicators. Journal of Cleaner Production, 18, 619-628.

49. Manjarrés, l. , Carrión, A ., Vega, J. (2009), The Effects of University-Industry Relationships and Academic Research On Scientific Performance: Synergy or Substitution?

https://doi.org/10.1007/s11162-009-9142-

50. Melville, Kraemer, \& Gurbaxani (2004) information Technology and Organizational Performance: An Integrative Model of IT Business Valu . disponible sur https://dl.acm.org/doi/10.5555/2017219.2017226 .

51. Mills, A., \& Smith, T. (2011). "Knowledge Management and Organizational Performance: A Decomposed View", Journal of Knowledge Management, 15(1): 156-171.

52. MULLEN, C.A. et Schunk, D.H. (2010). A view of professional learning communities through three frame: Leadership, organization, culture. McGill Journal of Education, 45(2), 185-203.

53. Neves. , $f(2017)$, Relation de la gestion des connaissances et la capacité d'innovation incrémentale dans trois industries traditionnelles. Gestion et management. Université Grenoble Alpes, 2016. Français. ffNNT : 2016GREAG010ff. fftel01485582.

54. Nonaka, I., (1994). A Dynamic Theory of Organizational Knowledge Creation. Organization Science, 5(1), pp.14-37.

55. Novak , A , (2017) , KNOWLEDGE MANAGEMENT AND ORGANIZATIONAL PERFORMANCE - LITERATURE REVIEW , Management, Knowledge and Learning , International Conference 2017 Technology, Innovation and Industrial Management.

56. Ramachandran, S., Chong, S., Wong, K. (2013), "Knowledge Management Practices and Enablers in Public Universities: A Gap Analysis, Campus-Wide Information Systems", 30(2): 76-94.

57. Ranjan, J.. \& Bhatnagar, V,. (2008). Principles for successful aCRM in organizations, Direct Marketing An International Journal 2(4):239-247, DOI: 10.1108/17505930810931035

58. Reich,B ,. Gemino , A,. Sauer, C . (2013). How knowledge management impacts performance in projects: An empirical study, ScienceDirect International Journal of Project Management 32 (2014) 590-602 .

59. Rossetti, A \& Morales,A, (2007), O papel da tecnologia da informação na gestão do conhecimento, DOI: $\quad 10.1590 / S 0100-$ 19652007000100009.

60. Sahibzada, U., Jianfeng, C. \& Latif, K. (2020). Interpreting the impact of knowledge management processes on organizational performance in Chinese higher education: mediating role of knowledge worker productivity, Studies in Higher Education, Volume 45, Issue 11.

61. Salama, S ., Isaac, O., Habtoor, N. (2020). Impact of Availability of Knowledge Management Infrastructure on Improving the Performance of The Education Sector Staff in Libya: Organizational Loyalty as a Mediating Variable, International Journal of Management and Human Science 
(IJMHS), eISSN: 2590-3748 URL: http://www.ijmhs.org.

62. Schutte, E., \& Toit. (2012). Knowledge creation processes as critical enablers for innovation International Journal of Information Management, Volume 32, Issue 4, August 2012, Pages 354-364

63. Shamia et al., (2018) (Using the Asian Knowledge Model "APO" as a Determinant for Performance Excellence in Universities- Empirical Study at Al Azhar University- Gaza.

64. Subram onya, M et al , (2018), " Leadership development practice bundles and organizational performance: The mediating role of human capital and social capital »

65. Szezerbicki, A. da S., Pilatti, L. A., et Carvalho, H. G. de. (2003). Evolução da gestão do conhecimento em indústria. UEPG Ci. Hum., Ci. Soc. Apl. Ling., Letras E Artes, 11(2), 57-62.

66. Tang , $Q$, (2012), "LA RELATION ENTRE LE STYLE DE LEADERSHIP ET LA PERFORMANCE D'UNE ÉQUIPE DE PROJET », UNIVERSITÉ DU QUÉBEC À RIMOUSKI, Mémoire de master .

67. Terra, J. C. C., Frederick, B., Vernalha, F., Romão, M., Manhães, M., et Leonardi, S. (2012). 10 Dimensões da Gestão da Inovação: uma abordagem para a transformação organizacional. Rio de Janeiro: Elsevier.

68. Vila, L ., Cabrer, B,. Pavía, J. ( 2015 ). On the relationship between knowledge creation and economic performance https://doi.org/10.3846/20294913.2013.876687, PP 539-556.

69. VROOM, V.H. et YETTON, P.W. (1973). Leadership and decision-making. Pittsburgh, PA: University of Pittsburgh Press.

70. Wenjiao D,. \& Yang H . (2020) . Research on Performance Evaluation of Knowledge Management Innovation in Colleges and Universitiehttps://doi.org/10.2991/aebmr.k.200708.0 54 Proceedings of the 4th International Symposium on Business Corporation and Development in SouthEast and South Asia under B\&R Initiative (ISBCD 2019) , ISBN 978-94-6252-983-0.

71. WORCHEL, S., JENNER, S. et HEBL, M. (1998). Changing the guard: How origin of new leader and disposition of ex-leader affect group performance and perceptions. Small Group Research, 29(4), 436451. 